\title{
CRISE DO JUDICIÁRIO: O ACESSO À JUSTIÇA GARANTIDO PELOS MÉTODOS ADEQUADOS DE SOLUÇÃO DE CONFLITOS
}

\author{
JUCIARY CRISIS: \\ THE ACCESS TO JUSTICE GUARANTEED BY THE \\ APPROPRIATE DISPUTE SOLUTION METHODS
}

DANIEL FIRMATO DE ALMEIDA GLÓRIA ${ }^{1}$ PAULO EDUARDO DINIZ RICALDONI LOPES ${ }^{2}$

\section{RESUMO}

O trabalho propõe analisar a efetividade do princípio do acesso à justiça diante dos números do Judiciário. Inicialmente, para entender a aplicação do princípio do acesso à justiça será estudada a sua definição. Após, serão analisados os dados do Judiciário para que possa verificar a situação dos tribunais nacionais. Por fim, os métodos adequados de resolução de conflito serão estudados como solução para garantir a efetividade do princípio e a redução do número de processos em tramitação. 0 presente artigo utiliza o método dedutivo e tem como referencial teórico a Constituição da República e o relatório Justiça em Números 2020.

PALAVRAS-CHAVE: Acesso à justiça. Crise no Judiciário. Métodos adequados de solução de conflitos.

\section{ABSTRACT}

The work proposes to analyze the effectiveness of the principle of access to justice considering the hyperbolic Judiciary statistics. Initially, to understand the application of the principle, it will be studier its definition. Afterwards, the Judiciary's data will be analyzed to check the situation of the national courts. Finally, the alternative dispute resolution methods will be studied as a solution to guarantee the effectiveness of the principle and the reduction of the number of processes in progress. This article uses the deductive method and its theoretical framework is the Constitution of the Republic and the Justice in Numbers 2020 report.

KEYWORDS: Access to justice. Judiciary Crisis. Appropriate dispute resolution.

1 Mestre (2001) e doutor em Direito Econômico pela Universidade Federal de Minas Gerais (2012). É professor de Direito Econômico e de Direito do Consumidor da Universidade FUMEC de Belo Horizonte. Defensor Público Coordenador da Defensoria Pública Especializada em Direito do Consumidor. Tem experiência na área de Direito, com ênfase em Direito Econômico e Direito do Consumidor. Além disso, possui experiência na coordenação de Curso de Direito, bem como na implementação e execução de projetos pedagógicos. Diretor do BRASILCON - Instituto Brasileiro de Política e Direito do Consumidor. ORCID iD: https://orcid.org/0000-0002-9560-520X. Lattes: http://lattes.cnpq.br/8418203288672612. E-mail: danielfirmato@ fumec.br.

2 Mestre em Direito Privado pela Universidade FUMEC. Pós Graduado em Direito Civil Aplicado pela Pontifícia Universidade católica de Minas Gerais (2014). Graduado em Direito pela Pontifícia Universidade Católica de Minas Gerais (2014). Gerente jurídico no Juris Correspondente. Tem experiência na área de Direito, com ênfase em Direito Privado, atuando principalmente em Direito Empresarial, do Consumidor e Mediação. ORCID iD: https://orcid.org/0000-0002-4485-7677. Lattes: http://lattes.cnpq.br/3270066796596842. E-mail: pauloricaldoni@gmail.com. pelos métodos adequados de solução de conflitos. Revista Meritum, Belo Horizonte, vol. 15, n. 2, p. 268-291, Maio/Ago. 2020. DOI: https://doi.org/10.46560/meritum.v15i2.8256. 


\section{INTRODUÇÃO}

A sociedade brasileira possui uma tradição litigiosa, na qual diante dos conflitos, busca em um terceiro (Judiciário) a tutela de seus direitos. Consequentemente, os tribunais nacionais encontram-se sobrecarregados com milhares de feitos em tramitação e novas ações são distribuídas, impossibilitando que as partes obtenham uma solução integral de mérito em prazo razoável. Atualmente, a força de trabalho nos tribunais não é capaz de efetivamente e em tempo razoável proferir a decisão de mérito, porém, diante do déficit financeiro do Judiciário, efetivar novos profissionais não é uma alternativa factível.

Trata-se de tema de extrema importância, pois diante do cenário observado nos tribunais, o princípio do acesso à justiça não é efetivamente e integralmente realizado, vez que, muito embora a apreciação judicial dos conflitos (acesso à jurisdição) ocorra, os mesmos não são julgados em tempo hábil. Consequentemente, diante da situação em que o acervo judicial se encontra, não são raras as vezes em que o objeto da ação se perde devido ao longo decurso de prazo entre a distribuição do feito até a baixa definitiva, trazendo prejuízos e custos desnecessários para o Estado e para as partes.

Para que seja possível reduzir o acervo sem depender diretamente do Judiciário, o legislador estipulou no parágrafo $3^{\circ}$, artigo $3^{\circ}$ do Código de Processo Civil (CPC) que os operadores do Direito devem antes e durante os feitos incentivar a utilização de métodos adequados de solução de conflitos autocompositivos. Assim, o trabalho propõe analisar se, diante da inefetividade do princípio do acesso à justiça, comprovada pelos números apresentados pelo Conselho Nacional de Justiça, os métodos adequados de resolução de conflito são viáveis para garantir a solução dos imbróglios dos cidadãos, bem como redução do efetivo processual no Judiciário

No capítulo de número dois, buscou-se um breve levantamento histórico do princípio do acesso à justiça desde seus primórdios, para, em seguida no capítulo três, ser abordada a sua definição para o Estado Democrático de Direito. Outrossim, foi destacado que a Justiça não pode ser confundida com a jurisdição, de modo que além de garantir aos cidadãos o direito de buscar no Judiciário a solução de suas controversas, estes devem ser solucionados de maneira efetiva e em tempo hábil.

No capítulo quatro, utilizou-se o relatório 'Justiça em números' disponibilizado pelo Conselho Nacional de Justiça (CNJ) referente ao ano de 2019, para confirmar a hipótese de crise do acervo judicial decorrente do elevado número de feitos em tramitação e os consequentes prejuízos que a demora na resolução dos litígios causa ao jurisdicionado.

Por fim, o último capítulo apresenta os métodos adequados de resolução de conflito como solução para garantir a satisfação dos cidadãos que poderão em conjunto ou com auxílio de terceiro buscar um acordo que traga benefícios de ganhos mútuos, retirando a incerteza de um processo judicial e em menor tempo, consequentemente, reduzindo o número de novos feitos.

Para possibilitar a pesquisa, foi utilizado o método hipotético-dedutivo, por meio de uma pesquisa bibliográfica (livros, artigos, dissertações, teses, revistas, legislações, dentre outros) para buscar diferenciar o acesso à justiça de acesso à jurisdição e em seguida, utilizando-se da análise de dados, averiguar a situação do acervo judicial no país. Por fim, foram 
apresentados os métodos adequados de solução de conflito como proposta para garantir maior efetividade ao princípio do acesso à justiça.

\title{
2. A EVOLUÇÃO HISTÓRICA DO ACESSO À JUSTIÇA
}

Em seus primórdios, o princípio do acesso à justiça foi previsto pela Magna Carta de 1215, a qual em seu artigo 40 estipulou que "a ninguém venderemos, a ninguém negaremos ou retardaremos direito ou justiça (LIBRARY, 2014, tradução nossa ${ }^{3}$ ). Porém, por ter sido concebida sobre a concepção de Estado absolutista as liberdades individuais eram limitadas pela nobreza. Contudo, mesmo que quase a integralidade da população vivesse sobre as baixas condições impostas pela monarquia, o Liberalismo somente se fortificou quando a burguesia insatisfeita com a falta de liberdade em gerir seus lucros e empreendimentos tomou frente junto a revolução.

\begin{abstract}
Em linhas gerais, o Estado Liberal caracteriza-se pela omissão perante os problemas sociais e econômicos, não consagrando direitos sociais e econômicos no seu texto além da regra básica de não intervenção no domínio econômico. As constituições liberais declaram os direitos individuais, entendidos como direitos que regulam condutas individuais e protegem a esfera de interesses individuais, contra o Estado, sendo o limite desses direitos o direito do outro, além de assegurarem ainda os direitos políticos. (MAGALHÃES, 2002, p. 63).
\end{abstract}

A busca da burguesia pela redução do controle do Estado na esfera privada, para que pudesse de forma livre gerir suas riquezas e usufruí-la da forma que decidir é perfeitamente expressa pela famosa frase "laissez faire, laissez aller, laissez passer" que em tradução literal significa "deixai fazer, deixai ir, deixai passar". Ademais, para Adam Smith, o Estado ou seus representantes, devem se limitar à defesa da nação em relação a inimigos, proteger seus cidadãos e garantir as condições básicas para as obras públicas (SMITH, 1996).

Em conseqüência (sic), a proporção entre o capital e a renda parece regular em todo lugar a proporção entre pessoas trabalhadoras e pessoas ociosas. Onde quer que predomine o capital, prevalece o trabalho; e onde quer que predomine a renda, prevalece a ociosidade. Por isso, todo aumento ou diminuição de capital tende a aumentar ou a diminuir a quantidade real de trabalho, o contingente de cidadãos produtivos e, conseqüentemente (sic), o valor de troca da produção anual da terra e do trabalho do país, a riqueza e renda reais de todos os seus habitantes. Os capitais são aumentados pela parcimônia e diminuídos pelo esbanjamento e pela má administração.

[...]

Assim como o capital de um indivíduo só pode ser aumentado por aquilo que poupa de sua renda anual ou de seus ganhos anuais, da mesma forma o capital de uma sociedade, que é equivalente à soma dos capitais de todos os indivíduos que a compõem, só pode ser aumentado dessa maneira. A parcimônia, e não o trabalho, é a causa imediata do aumento de capital. Com efeito, o trabalho fornece o objeto que a parcimônia acumula. Com tudo o 
que o trabalho consegue adquirir, se a parcimônia não economizasse e não acumulasse, o capital nunca seria maior. (SMITH, 1996, p. 129).

O Estado mínimo liberal foi o marco inicial para a proteção efetiva de direitos naturais da população, cabendo ao ente estatal se abster de assuntos privados e apenas garantir a existência dos direitos.

A burguesia, classe dominada, a princípio e, em seguida, classe dominante, formulou os princípios filosóficos de sua revolta social.

E, tanto antes como depois, nada mais fez do que generalizá-los doutrinariamente como ideias comuns a todos os componentes do corpo social. Mas, no momento em que se apodera do controle político da sociedade, a burguesia já se não interessa em manter na prática a universalidade daqueles princípios, como apanágio de todos os homens, Só de maneira formal os sustenta, uma vez que no plano de aplicação política eles se conservam, de fato, princípios constitutivos de uma ideologia de classe. (BONAVIDES, 2001, p. 42).

No paradigma do Estado Liberal (construído com a ideologia burguesa), os métodos para resolução de conflitos espelhavam o caráter individualista dos direitos, ou seja, o Estado deveria manter sua atuação mínima, apenas garantindo a ordem e protegendo liberdades individuais.

Direito ao acesso à proteção judicial significava essencialmente o direito formal (sic) do indivíduo agravado de propor ou contestar uma ação. A teoria de que, embora o acesso à justiça pudesse ser um 'direto natural', os direitos naturais não necessitavam de uma ação do Estado para sua proteção. Esses diretos eram considerados anteriores ao Estado: sua preservação exigia apenas que o Estado não permitisse que eles fossem infringidos por outros. o Estado, portanto, permanecia passivo, com relação a problemas tais como a aptidão de uma pessoa para reconhecer seus direitos e defendê-los adequadamente, na prática (sic). (CAPPELLETTI; GARTH, 2002, p. 9).

Ainda segundo os autores, para a concepção liberal, não era obrigação do ente estatal garantir indiscriminadamente a atuação jurisdicional, devendo existir apenas o acesso formal à justiça (de forma restrita). Logo, somente os cidadãos que possuíssem condições de custear a defesa de seus direitos, poderiam buscar em juízo a apreciação de seus litígios (CAPPELLETTI; GARTH, 2002).

O aprimoramento econômico e o consequente desenvolvimento industrial provenientes do Estado Liberal acarretaram um acelerado e sem planejamento êxodo rural, criando centros urbanos superpovoados, sem condições básicas de saúde e trabalho para os cidadãos que "sobreviviam" em condições precárias. A igualdade formal, exploração do proletariado e a autorregulação do mercado, deram início aos questionamentos quanto não intervencionismo do Estado.

As Constituições do México (1917) e de Weimar (1919) trazem em seu bojo novos direitos que demandam uma contundente ação estatal para sua implementação concreta, a rigor destinados a trazer consideráveis melhorias nas condições materiais de vida da população em geral, notadamente da classe trabalhadora. Fala-se em direito à saúde, à moradia, à alimentação, à educação, à previdência etc. Surge um novíssimo ramo do Direito, voltado a compensar, no plano jurídico, o natural desequilíbrio travado, no plano fático, entre o capital e o trabalho. O Direito do Trabalho, assim, emerge como um 
valioso instrumental vocacionado a agregar valores éticos ao capitalismo, humanizando, dessa forma, as até então tormentosas relações jus laborais. No cenário jurídico em geral, granjeia destaque a gestação de normas de ordem pública destinadas a limitar a autonomia de vontade das partes em prol dos interesses da coletividade. (SARMENTO, 2006, p. 13).

A sociedade burguesa aproveitou-se da mobilização da população em geral para substituir o regime feudal, mas após a sua ascensão, tomou para si o poder estatal e criou novas formas de opressão. Utilizando novas tecnologias aperfeiçoou os meios de produção para conseguir manufaturar bens com custos inferiores aos das nações rivais que ainda eram reguladas sobre o regime feudal, obrigando estes países a adotar a mesma forma de governo, sob pena de extinção do Estado (MARX, ENGELS, 2014). Como resultado, as grandes cidades receberam um montante populacional superior as suas capacidades, agravando as condições degradantes que os cidadãos sobreviviam. Desse modo, a nova força revolucionária, considerou necessário que o Estado abandonasse o individualismo e passasse a adotar um pensamento comunitário em busca da garantia dos interesses de todos. (MARX, ENGELS, 2014).

Sob forma de máquinas, o meio de trabalho imediatamente tornase o concorrente do operário. 0 rendimento do capital está em razão direta com o número de operários cujas condições de existência foram aniquiladas pela máquina. Desde que o manejo da ferramenta é executado pela máquina, a força do trabalho perde, por sua vez, em seu valor de troca e em seu valor de uso. 0 operário, como o papelmoeda fora de circulação, tornase não comerciável. A parte da classe operária que o emprego das máquinas transforma ao acaso em população supérflua, isto é, em população da qual o capital não tem mais necessidade direta para assegurar seu rendimento, sucumbe na luta desigual da antiga exploração profissional ou manufatureira contra a exploração mecânica, enchendo o mercado e fazendo cair o preço da força de trabalho abaixo de seu valor. Os operários jogados na miséria têm um duplo consolo, dizendo que seus sofrimentos são passageiros e que a máquina invade lentamente um campo de produção, o que quebra a intensidade e a extensão de seu trabalho destruidor. Esses dois consolos se anulam. Em todos os lugares em que a máquina se apodera de uma área da produção, ela engendra a miséria crônica em sua concorrente: a classe operária. (MARX, 2018).

Defensora do Estado mínimo, a burguesia considerou inviável o ente público tutelar a população, todavia, em face de eminentes ameaças revolucionárias, os governos foram obrigados a adotar propostas sociais, especialmente as oriundas do proletariado que mesmo tendo sido uma peça fundamental da transição do Absolutismo para o Liberalismo não teve seus anseios e reivindicação consideradas (ALBUQUERQUE; BARROSO 2018). Como estratégia para frear essas revoluções, foram adotados mecanismos de proteção ao hipossuficiente como a igualdade material, intervenção estatal e um melhor balanceamento entre mercado e sociedade. Assim, como um dos fundamentos do Estado Social é a dignidade da pessoa humana, o Estado deveria além de criar direitos, instaurar instrumentos suficientes para que fossem efetivados.

A constante evolução da sociedade originou novas formas de Estado, nas quais os direitos abandonaram o seu caráter exclusivamente individualista em busca de uma proteção ampla de todos os seus membros. Para o paradigma do Estado Social, fundamentado na 
solidariedade e dignidade da pessoa humana, o ente estatal não deve apenas criar direitos, mas possibilitar instrumentos capazes de torná-los efetivos.

A diferença básica entre a concepção clássica do liberalismo e a do Estado de Bem-Estar é que, enquanto naquela se trata tão-somente de colocar barreiras ao Estado, esquecendo-se de fixar-Ihe também obrigações positivas, aqui, sem deixar de manter as barreiras, se lhes agregam finalidades e tarefas às quais antes não sentia obrigado. A identidade básica entre o Estado de Direito e Estado de Bem-Estar, por sua vez, reside em que o segundo toma e mantém do primeiro o respeito aos direitos individuais e é sobre esta base que constrói seus próprios princípios. (GORDILLO, 1977, p. 174).

Novamente, decorrente da evolução da consciência e da sociedade, foi concebido o paradigma do Estado Democrático de Direito tendo como alguns de seus princípios fundamentais a soberania popular como origem do Poder Estatal e a primazia da legalidade, mesclando pontos dos Estados Liberais e Democráticos (BOBBIO, 1986).

Estado Liberal e estado democrático são interdependentes em dois modos: na direção que vai do liberalismo à democracia, no sentido de que são necessárias certas liberdades para o exercício correto do poder democrático, e na direção oposta que vai da democracia ao liberalismo, no sentido de que é necessário o poder democrático para garantir a existência e a persistência das liberdades fundamentais. Em outras palavras: é pouco provável que um estado não liberal possa assegurar um correto funcionamento da democracia, e de outra parte é pouco provável que um estado não democrático seja capaz de garantiras liberdades fundamentais. (BOBBIO, 1986, p. 20).

Nesta interlocução entre paradigmas, a liberdade somente pode ser garantida pelo Estado se existir uma democracia que permita a conservação e desenvolvimento de garantias individuais com base no texto constitucional. Assim, sob o paradigma do Estado Democrático de Direito, o efetivo princípio do acesso à justiça é de fundamental relevância para os direitos individuais, coletivos, difusos e transindividuais, pois diante da ausência do princípio, a população não possuiria meios de efetivar suas garantias fundamentais.

Desta forma, trata-se o Estado Democrático de Direito de uma nova ordem que colaciona preceitos dos paradigmas do direito liberal e do direito social, o que significa a junção dos princípios do Estado de Direito e do Estado Democrático, ou seja, ele promove a limitação do exercício do poder do Estado com a supremacia da Constituição da República e a democracia de processo, na qual o magistrado deve afastar a aplicação de normas contrárias à Constituição da República, visando sempre a efetivação dos direitos fundamentais. (CAMARGOS, 2020, p. 20).

No Brasil, o princípio do acesso à justiça como direito fundamental foi estipulado em um primeiro momento na Constituição dos Estados Unidos do Brasil de 1946, tendo sido determinado no parágrafo $4^{\circ} \mathrm{do}$ artigo 141 que "a lei não poderá excluir da apreciação do Poder Judiciário qualquer lesão de direito individual" (BRASIL, 1946). Todavia, em 1964 com o Golpe de Estado, o princípio foi mitigado primeiramente pelo Ato Institucional $n^{\circ} 2$ que excluiu da apreciação pelo Judiciário:

I - os atos praticados pelo Comando Supremo da Revolução e pelo Governo federal, com fundamento no Ato Institucional de 9 de abril de 1964, no presente Ato Institucional e nos atos complementares deste; 
II - as resoluções das Assembléias Legislativas e Câmara de Vereadores que hajam cassado mandatos eletivos ou declarado o impedimento de Governadores, Deputados, Prefeitos ou Vereadores, a partir de 31 de março de 1964, até a promulgação deste Ato. (BRASIL, 1965).

Posteriormente, quando da promulgação do Ato Institucional $n^{\circ} 5$, foi determinado que:

O Presidente da República poderá decretar a intervenção nos estados e municípios, sem as limitações previstas na Constituição, suspender os direitos políticos de quaisquer cidadãos pelo prazo de 10 anos e cassar mandatos eletivos federais, estaduais e municipais, e dá outras providências.[...]

Art. 11 - Excluem-se de qualquer apreciação judicial todos os atos praticados de acordo com este Ato institucional e seus Atos Complementares, bem como os respectivos efeitos. (BRASIL, 1968).

Tal mitigação perdurou até 1978, quando a Emenda Constitucional n 11 em seu artigo $3^{\circ}$ revogou os "atos institucionais e complementares, no que contrariarem a Constituição da República de 1988, ressalvados os efeitos dos atos praticados com bases neles, os quais estão excluídos de apreciação judicial" (BRASIL, 1978).

Por fim, em 1988, com a promulgação da Constituição da República, o constituinte originário exercendo o papel de representante do povo, instituiu já no preâmbulo, a adoção do Estado Democrático com base no exercício e garantia dos direitos sociais, individuais, liberdade, justiça, dentre outros.

\section{O PRINCÍPIO DO ACESSO À JUSTIÇA}

Em uma sociedade fundada sob o paradigma do Estado Democrático de Direito, efetivar o princípio do acesso à justiça é de fundamental importância para que todos os direitos (individuais, coletivos, difusos e transindividuais) possam ser garantidos à população.

A expressão 'acesso à Justiça' é reconhecidamente de difícil definição, mas serve para determinar duas finalidades básicas do sistema jurídico - o sistema pelo qual as pessoas podem reivindicar os seus direitos e/ou resolver seus litígios sob os auspícios do Estado. Primeiro, o sistema deve ser igualmente acessível a todos; segundo, ele deve produzir resultados que sejam individualmente e socialmente justos. (CAPPELLETTI; GARTH, 2002, p. 8).

Para que o princípio do acesso à justiça seja efetivamente compreendido, é preciso buscar uma definição para justiça. Aristóteles, em sua obra Ética a Nicômaco inicialmente a define como "aquela disposição de caráter que torna as pessoas propensas a fazer o que é justo, que as faz agir justamente e desejar o que é justo; e de mesmo modo, por injustiça se entende a disposição que as leva a agir injustamente e a desejar o que é injusto." (ARISTÓTELES, 1991, p. 94).

Ciente de que a definição de justiça não é uma tarefa simplória, destrincha sua afirmação, conceituando o homem justo como o indivíduo honesto e respeitador as leis, o qual detêm a maior das virtudes ao exercê-la perante outros, agindo de modo que traga benefícios para todos e não somente para si (ARISTÓTELES, 1991). É possível perceber contornos da igualdade material quando o filosofo assimila como cada sujeito possui diferenças, ser 
justo não é garantir as mesmas condições, mas tratar os iguais de maneira semelhante e os diferentes de modo diverso.

Ora, nas disposições que tomam sobre todos os assuntos, as leis têm em mira a vantagem comum, quer de todos, quer dos melhores ou daqueles que detêm o poder ou algo nesse gênero; de modo que, em certo sentido, chamamos justos aqueles atos que tendem a produzir e a preservar, para a sociedade política, a felicidade e os elementos que a compõem. E a lei nos ordena praticar tanto os atos de um homem bravo (por exemplo, não desertar de nosso posto, nem fugir, nem abandonar nossas armas) quanto os de um homem temperante (por exemplo, não cometer adultério nem entregar-se à luxúria) e os de um homem calmo (por exemplo não bater em ninguém, nem caluniar); e do mesmo modo com respeito às outras virtudes e formas de maldade, prescrevendo certos atos e condenando outros; e a lei bem elaborada faz essas coisas retamente, enquanto as leis concebidas às pressas as fazem menos bem. (ARISTÓTELES, 1991, p. 96).

John Rawls em sua obra 'Uma teoria da justiça' ensina que todos os indivíduos devem possuir direitos indisponíveis, ou seja, aqueles que nem mesmo em face do suposto bem estar social poderão ser mitigados (RAWLS, 2000).

Cada pessoa possui uma inviolabilidade fundada na justiça que nem mesmo o bem-estar da sociedade como um todo pode ignorar. Por essa razão, a justiça nega que a perda da liberdade de alguns se justifique por um bem maior partilhado por outros. Não permite que os sacrifícios impostos a uns poucos tenham menos valor que o total maior das vantagens desfrutadas por muitos. Portanto numa sociedade justa as liberdades da cidadania igual são consideradas invioláveis; os direitos assegurados pela justiça não estão sujeitos à negociação política ou ao cálculo de interesses sociais. A única coisa que nos permite aceitar uma teoria errônea é a falta de uma teoria melhor; de forma análoga, uma injustiça é tolerável somente quando é necessária para evitar uma injustiça ainda maior. Sendo virtudes primeiras das atividades humanas, a verdade e a justiça são indisponíveis. (RAWLS, 2000, p. 4).

Em uma sociedade (diante das diferenças pré-existentes como condição social), é comum que cidadãos sofram favorecimentos ou detrimento decorrentes destas condições, cabendo à justiça tutelar essas desigualdades e garantir que direitos e deveres fundamentais sejam igualmente garantidos entre os seus membros (RAWLS, 2000).

A essa maneira de considerar os princípios da justiça eu chamarei de justiça como equidade (sic).

Assim, devemos imaginar que aqueles que se comprometem na cooperação social escolhem juntos, numa ação conjunta, os princípios que devem atribuir os direitos e deveres básicos e determinar a divisão de benefícios sociais. Os homens devem decidir de antemão como devem regular suas reivindicações mútuas e qual deve ser a carta constitucional de fundação de sua sociedade. Como cada pessoa deve decidir com o uso da razão o que constitui o seu bem, isto é, o sistema de finalidades que, de acordo com sua razão, ela deve buscar, assim um grupo de pessoas deve decidir de uma vez por todas tudo aquilo que entre elas se deve considerar justo e injusto. A escolha que homens racionais fariam nessa situação hipotética de liberdade 
equitativa, pressupondo por ora que os problemas da escolha têm uma solução, determina os princípios da justiça.

$\mathrm{Na}$ justiça como equidade (sic) a posição original de igualdade corresponde ao estado de natureza na teoria tradicional do contrato social. Essa posição não é, obviamente, concebida como uma situação histórica real, muito menos como uma condição primitiva de cultura. É entendida como uma situação puramente hipotética caracterizada de modo a conduzir a uma certa concepção de justiça. (RAWLS, 2000, p. 13).

Rawls ensina que a justiça formal somente será efetiva quando a justiça equitativa (aquela que deve ser aceita consensualmente e aplicável a todos sem exceção) é aceita pelos cidadãos e diante das peculiaridades de cada caso apresentado tratada de forma imparcial por juízes e autoridades (RAWSL, 2000).

Tratar casos similares de modo similar não basta para garantir uma justiça substantiva. Isso depende dos princípios de acordo com os quais a estrutura básica é montada. Não há contradição em supor que uma sociedade escravocrata ou de castas, ou alguma outra sociedade que sanciona as formas mais arbitrárias de discriminação, seja administrada de forma equilibrada e consistente, embora isso possa ser improvável. No entanto, a justiça formal, ou justiça como regularidade, exclui tipos significativos de injustiças. Pois se supomos que as instituições são razoavelmente justas, é então de grande importância que as autoridades devam ser imparciais e não se submetam à influência de considerações pessoais, monetárias ou quaisquer outras considerações irrelevantes ao lidarem com casso particulares. A justiça formal no caso das instituições legais é meramente um aspecto do estado de direito que apóia (sic) e assegura expectativas legítimas. Um tipo de injustiça é falha dos juízes e de outras autoridades que não aderem às regras e interpretações adequadas no julgamento de reivindicações. Uma pessoa é injusta na medida em que por caráter e inclinação está disposta a tais atos. Além disso, mesmos nos casos em que as leis e instituições são injustas, muitas vezes é melhore que elas sejam consistentemente aplicadas. Desse modo, aqueles submetidos a elas pelo menos sabem o que lhes é exigido e podem se proteger adequadamente; ao passo que existe uma injustiça ainda maior se os que já estão em desvantagem são tratados de forma arbitrária em casos particulares em que as regras Ihes dariam alguma segurança. [...] Em geral, tudo o que se pode dizer é que a força das exigências da justiça formal, da obediência do sistema, depende claramente da justiça substantiva das instituições e da possibilidade de reforma. (RAWLS, 2000, p. 62-63).

O pensamento de Rawls se adequa perfeitamente a realidade do Estado Democrático de Direito por possuir um caráter inclusivo de indivíduos que almejam realizar projetos pessoais em condições iguais (mesmo que apenas formal) de modo que o cidadão se torna o próprio autor das normas criadas e não apenas um destinatário (MORAIS, 2007).

Principalmente, no Estado Democrático de Direito, o acesso à Justiça integra o rol de Direitos Humanos, sendo fundamental a sua garantira para que os demais possam ser reconhecidos. Ademais, para a sociedade ter a efetiva garantia de seus direitos, se mostra primordial que seja ampliada, se torne mais justa e célere a prestação judicial, incumbindo ao estado o dever de conceber instrumentos que o concretizem (ANNONI, 2006).

No Brasil, para efetivar a apreciação judicial dos conflitos, a capacidade econômica das partes não pode ser um impedimento, assim, por meio da gratuidade da justiça, as custas 
judiciais serão suspensas porquanto a parte não tiver condições de arcar com as mesmas (BRASIL, 2015). Igualmente, foram criados os juizados especiais com isenção de custas, taxas, despesas e honorários advocatícios em primeiro grau (artigo 54 e seguintes da Lei 9.099/95) (BRASIL, 1995). Por fim, a Defensoria Pública foi instituída como fundamental instrumento de promoção dos direitos humanos com a defesa gratuita e integral dos direitos individuais e coletivos a todos que não possuem condições, mas precisam da tutela judicial ou extrajudicial (artigo 134 da CR/88).

A Constituição Federal de 1988 é considerada uma das mais completas do mundo ao tratar de direitos e garantias fundamentais, pois consagrou a igualdade material, garantindo a todos os brasileiros a redução da desigualdade social, bem como a assistência judiciária gratuita aos necessitados, à criação dos juizados especiais para as causas de menor complexidade e crimes de menor potencial ofensivo, reestruturou e fortaleceu o Ministério Público e reorganizou a Defensoria Pública. (SEIXAS; SOUZA, 2013, p. 82).

Conforme pontua Adriana Silva, justiça não deve ser confundida com jurisdição, sendo a primeira relacionada como a busca pela solução do conflito com o saneamento das divergências e a segunda como "dizer o direito, dar a solução ao caso proposto, sem, no entanto, preocupar-se necessariamente com o contentamento ou a satisfação das partes" (SILVA, 2005, p. 87).

Corroborando com este entendimento, Bruno Salles, apresenta o princípio em duas concepções: a primeira, também chamada de "Acesso ao Poder Judiciário ou aos tribunais" é aquela que é efetivada ao garantir o exercício do direito de ação junto a um Judiciário devidamente institucionalizado; a segunda, possui um sentido mais amplo, possibilitando ao cidadão a ampla informação jurídica e outras formas de acessibilidade aos seus direitos, ainda que fora da organização Jurisdicional, sendo denominada pelo autor como "Acesso ao Direito ou aos Direitos" (SALLES, 2019).

Por acesso à justiça tem se entendido, majoritariamente, por princípio constitucional que fundamenta o direito de acesso aos tribunais, o direito de recorrer da violação de direito subjetivo. Tal acepção está em perfeita sintonia com o Estado Democrático, que deve ser erguido segundo o mandamento da Constituição em seu art. $1^{\circ}$. Todavia, o acesso à justiça, no nosso sentir, abarca outras características além da dimensão processual. Consideramos esse aspecto sumamente importante, porém, ao não trazê-lo para a discussão na sua devida relevância - impedimentos que impossibilitam o cidadão o pleno acesso à justiça -, estaremos sobremaneira enfatizando a pura instrumentalidade em detrimento da substancialidade do preceito constitucional. (ROCHA; ALVES, 2011, p. 133-134).

Ciente de que somente garantir que os conflitos sejam apreciados pelo Judiciário não garantem a efetividade do acesso à justiça, o CPC em seu artigo $4^{\circ}$ estipula que "as partes têm o direito de obter em prazo razoável a solução integral do mérito, incluída a satisfativa" (BRASIL, 2015). Igualmente, a Convenção Europeia dos Direitos do Homem, utilizando-se como base a Declaração Universal dos Direitos do Homem, atenta a efetividade processual, convencionou que qualquer pessoa terá direito "que a sua causa seja examinada, equitativa e publicamente, num prazo razoável por um tribunal independente e imparcial, estabelecido pela lei" (ECHR, 1950). 
Um excelente exemplo da garantia da jurisdição, mas não da justiça, é o processo distribuído em 1885 pelo Conde e Condessa d'Eu requerendo a posse do Palácio Guanabara que foi objeto de esbulho pelo Marechal Deodoro da Fonseca durante a proclamação da república, que somente após 125 anos (em 2020) ocorreu o trânsito em julgado dos últimos recursos interpostos perante ao Supremo Tribunal Federal. Dois anos antes, decorridos mais de 123 anos desde sua distribuição, o Recurso Especial n 1.149.487/RJ4 (BRASIL, 2019a) e o Recurso Especial 1.141.490/RJ ${ }^{5}$ (BRASIL, 2019b) foram julgados pelo Superior Tribunal de Justiça. Por fim, após o decurso de 125 anos, os recursos de Agravo de Instrumento $n^{\circ} 761.820 / R J$ (BRASIL, 2020d) e Agravo de Instrumento $n^{\circ} 764.506 / R J$ (BRASIL, 2020e), sobrestados enquanto aguardavam decisão do Superior Tribunal de Justiça (STJ), bem como o Agravo Regimental no Recurso Extraordinário com Agravo n 1.250.467/RJ (BRASIL, 2020f) foram conhecidos, mas o seu seguimento foi negado por não ter sido identificada ofensa a preceito constitucional.

O litígio instaurado pela família imperial soa como uma realidade distante, porém, a demora processual traz prejuízos aos cidadãos em situações cotidianas como por exemplo o divórcio de um casal com filhos menores. De acordo com o artigo 733 do CPC, mesmo que exista o acordo entre os cônjuges, caso tenham filhos menores, deverão obrigatoriamente requerer a homologação do acordo (BRASIL,2015). Todavia, devido à demora oriunda do elevado acervo processual, aquela criança até então incapaz, poderá atingir a maioridade antes que a transação seja homologada e as partes poderão desistir da lide para realizar o ato em cartório. 0 problema nesta situação é que o Judiciário ao não ser efetivo, foi desnecessariamente movimentado, sendo gerados custos as partes e para o Estado.

Evidente a importância do movimento denominado acesso à justiça e os mecanismos criados para garantir a inclusão de um número cada vez maior de cidadãos no Judiciário.

Ocorre que esses mecanismos de acesso à justiça, que resultaram em uma avalanche de ações, deram causa a outro problema: o andamento da litigiosidade e a morosidade na prestação jurisdicional.

Portanto, não basta criar apenas mecanismos de acesso formal à justiça, permitindo-se o mero acesso ao Poder Judiciário, sem se preocupar com o aumento progressivo da litigiosidade e a consequente morosidade da tutela jurisdicional. É preciso enfrentar o fenômeno da excessiva litigiosidade de massa e assegurar efetiva e tempestiva prestação jurisdicional com isonomia. Tutela justa não é apenas aquela prestada tempestivamente. (ZANFERDINI; MAZZO, p. 94-95, 2015).

Ademais, para o Estado Democrático de Direito, deve-se adotar uma concepção de justiça coexistencial que compreende além da resolução da lide (em sua totalidade) a manutenção das relações entre os indivíduos. De modo diverso da "justiça tradicional" em que

4 O bem foi obtido com a utilização de recursos do Tesouro Nacional como dote e somente poderia ser utilizado como morada da família imperial. Com a proclamação da República, os privilégios reais e títulos nobiliárquicos foram extintos, bem como as Leis $n^{\circ}$ 166/1840 e 1.904/1870 estipularam que os bens utilizados para moradia da família imperial eram propriedades da Fazenda Nacional. Desse modo em primeiro grau entendeu-se que como o bem pertence a União e com o fim da monarquia os condes não possuem mais títulos garantidores de sua propriedade, inexiste qualquer violação ao direito de posse. Entendimento esse que foi confirmado pelo $2^{\circ}$ grau e pela a Quarta Turma do STJ.

50 segundo feito tem como objeto a ação reivindicatória proposta pelos herdeiros do Conde e da Condessa d'Eu requerendo a restituição do Palácio ao espólio imperial ou, caso não fosse possível, a conversão em indenização. Em primeiro grau, foi acolhida a preliminar de prescrição trintenária, o qual foi confirmada pela Terceira Turma do TRF-2ª Região e pela Quarta Turma do STJ. 
uma das partes é vencedora e a outra derrotada, a justiça coexistencial busca o consenso do litígio (SILVA, 2005).

A Justiça coexistencial, ao contrário, não está destinada a trancher (sic), a decidir e definir, mas antes a remendar (precisamente de uma mending justice - Justiça de consertos), para aliviar situações de ruptura ou de tensão, com o fim de preservar um bem durável, qual seja, a pacífica convivência dos sujeitos que fazem parte de um grupo ou de uma relação complexa, de cujo meio dificilmente poderiam subtrairse (sic). A justiça contenciosa não se preocupa tanto com estes valores, posto que olha mais para o passado do que para o futuro. A Justiça contenciosa vai muito bem para as relações do tipo tradicional, mas não para aquelas que têm se apresentado com as mais típicas e constantes da sociedade contemporânea, para as quais assume especial importância aquilo que os sociólogos denominam de total institutions, ou seja, instituições integrais, nas quais nós, enquanto membros de várias comunidades econômicas, culturais ou sociais, ficamos compelidos a despender uma parte ponderável da nossa vida e da nossa atividade: fábricas, escolas, condomínios, freguesias de bairro, etc. [...]

Nestas relações não se ajusta facilmente o nobre ideal oitocentesco (sic) e burguês da luta pelo direito. O Kampf ums Recht deve dar lugar ao Kampf um die Billigkeit, ou seja, à luta pela equidade (sic), por uma solução justa e aceitável por todos os contendores. Nestas situações, aquela busca da verdade para se saber quem teve razão e quem não teve razão (no passado), deve encaminhar-se para a busca de uma possibilidade de permanência e de convivência (no futuro), sempre no interesse das próprias partes. (CUNHA, 2015, p. 66).

Nesta concepção, a Justiça ultrapassa a própria jurisdição, devendo o Estado garantir (além da solução de mérito do litígio) a devida apreciação do conflito, para que, ao ser devidamente trabalhado, as relações que se encontram deterioradas ou desmanchadas possam ser restabelecidas.

Portanto, garantir aos cidadãos a possibilidade de terem seus litígios apreciados pelo Judiciário, é apenas uma parte do princípio do acesso à justiça, que para ser integralmente cumprido é necessário que a decisão seja prolatada em tempo hábil. Logo, utilizando dos métodos adequados de solução de conflitos (MASC) os indivíduos poderão em conjunto e com o auxílio de terceiros realizar à justiça em seu sentido amplo, qual seja, de forma satisfatória ter o interesse de cada um assegurado.

\section{A CRISE DO ACERVO JUDICIAL}

O Conselho Nacional de Justiça (CNJ) foi criado pela emenda constitucional no 45/2004 como órgão competente para o controle da atuação administrativa e financeira do Judiciário, sendo incumbido de elaborar relatório anual sobre a situação do Judiciário e propor providências necessárias de acordo com os dados apresentados (BRASIL, 1988). Sua missão é "desenvolver políticas judiciárias que promovam a efetividade e a unidade do Poder Judiciário, orientadas para os valores de justiça e paz social" (BRASIL, 2020b). 
Desde 2004 o relatório 'Justiça em Números' utilizando de análise de dados e estatísticas, contribuiu para a publicidade e transparência do Judiciário ${ }^{6}$ ao traduzir a realidade dos tribunais nacionais quanto a sua estrutura, litigiosidade, situação financeira, tempo de tramitação dos autos, BRASIL, 2020a).

O Relatório Justiça em Números e o principal documento de publicidade e transparência do Poder Judiciário, que consolida em uma única publicação dados gerais da atuação do Poder Judiciário e abrange informações relativas as despesas, as receitas, acesso à justiça e uma vasta gama de indicadores processuais, com variáveis que mensuram o nível de desempenho, de informatização, de produtividade e de recorribilidade da justiça.

diagnóstico, anualmente elaborado pelo Departamento de Pesquisas Judiciárias (DPJ), sob a supervisão da Secretaria Especial de Programas, Pesquisas e Gestão Estratégica (SEP) do CNJ, apresenta informações detalhadas por tribunal e por segmento de justiça, além de uma série histórica de 11 anos, de 2009 a 2019. As informações são apuradas desde o início da criação do CNJ e o primeiro relatório foi elaborado em 2006, com dados do ano-base 2004. Em 2009, em um processo de ampla revisão e aprimoramento dos glossários e indicadores do Sistema de Estatísticas do Poder Judiciário (SIESPJ), importantes alterações de conceito foram realizadas, e, por isso, os dados aqui apresentados adotam o recorte temporal a partir desse ano, mantido o histórico para consulta no próprio site do CNJ.

A $16^{\circ}$ edição do Relatório Justiça em Números reúne informações dos 90 órgãos do Poder Judiciário, elencados no art. 92 da Constituição da República Federativa do Brasil de 1988, excluídos o Supremo Tribunal Federal e o Conselho Nacional de Justiça. Assim, o Justiça em Números inclui: os 27 Tribunais de Justiça Estaduais (TJs); os cinco Tribunais Regionais Federais (TRFs); os 24 Tribunais Regionais do Trabalho (TRTs); os 27 Tribunais Regionais Eleitorais (TREs); os três Tribunais de Justiça Militar Estaduais (TJMs); o Superior Tribunal de Justiça (STJ); o Tribunal Superior do Trabalho (TST); o Tribunal Superior Eleitoral (TSE) e o Superior Tribunal Militar (STM). (BRASIL, 2020a, p. 9).

De acordo com o relatório, no ano de 2019 foram distribuídas mais de 30,2 milhões de novos feitos, enquanto 35,4 milhões foram definitivamente baixados, de modo que o Judiciário encerrou o ano com um total de quase 77,1 milhões de feitos em tramitação (BRASIL, 2020a). Desse total, 14,2 milhões (18,5\%) de feitos encontravam-se suspensos, sobrestado ou em arquivo provisório (BRASIL, 2020a), porém, mesmo que não estejam sendo efetivamente movimentados, são necessárias despesas com servidores encarregados dos arquivos e gastos com sua manutenção, por exemplo.

6 Os dados apresentados pelo CNJ em seu relatório anual não abrangem o Supremo Tribunal Federal (STF) os quais são apresentados em documento diverso (BRASIL, 2020a). 
Tabela 1 - Acervo judicial no ano de 2019

\begin{tabular}{l|c}
\hline & número de processos \\
\hline Em tramitação & 77.096 .939 \\
Novos & 30.214 .346 \\
Baixados & 35.384 .976 \\
Total do acervo (em tramitação + & 71.926 .309 \\
\hline
\end{tabular}

Fonte: Elaborado pelo autor com dados extraídos do CNJ (BRASIL, 2020a, p. 49).

O ano de 2019 foi marcado pela redução do número de processos em 4,08\% se comparado com o ano anterior, tendo a Justiça do Trabalho e a Justiça Estadual juntas reduziram o estoque em 2,7 milhões de feitos, sendo as principais responsáveis pela redução (BRASIL, 2020a). Por sua vez, durante os anos de 2018-2019, o índice acumulado de redução do acervo judicial foi de $3 \%$, todavia, mesmo que pareça promissor, se for mantida a média anual de redução de 2,9 milhões de processos, serão necessários 25 anos para se encerrar os 72 milhões de autos em tramitação nos tribunais nacionais.

A força de trabalho existente no Judiciário no referido ano era de 268.175 servidores e 18.091 magistrados, sendo que 15.552 julgadores estavam alocados na $1^{\mathrm{a}}$ instância e 2.808 acumulavam funções juizados especiais e 1.115 nas turmas recursais (BRASIL, 2020a).

Tabela 2 - Força de Trabalho da Magistratura

\begin{tabular}{lc}
\hline & Magistrados \\
\hline Cargos disponíveis & 22.706 \\
Cargos vagos & 4.615 \\
Em exercício & 18.091 \\
$1^{\circ} \mathrm{Grau}$ & 15.552 \\
$2^{\circ} \mathrm{Grau}$ & 2.463 \\
\multicolumn{1}{c}{ Tribunais Superiores } & 76 \\
\hline
\end{tabular}

Fonte: Elaborado pelo autor com dados extraídos do CNJ (BRASIL, 2020a, p. 86). 
Tabela 3 - Força de Trabalho de Servidores

\begin{tabular}{lcc}
\hline & Servidores \\
\hline Cargos disponíveis & 276.331 \\
Cargos vagos & 8.156 \\
Em exercício & 268.175 \\
\multicolumn{1}{c}{ Área judiciária } & 211.295 \\
& $1^{\circ}$ Grau & 176.992 \\
& $2{ }^{\circ}$ Grau & 30.920 \\
& Tribunais Superiores & 3.383 \\
Área Administrativa & 56.880 \\
\hline
\end{tabular}

Fonte: Elaborado pelo autor com dados extraídos do CNJ (BRASIL, 2020a, p. 86).

Tomando como base o total de feitos no acervo judicial (71.926.309), o número de magistrados em exercício (18.091) e o total de servidores atuantes (268.175), ao final do ano de 2019, cada julgador tinha sobre seus cuidados 3.976 processos e apenas 15 servidores para auxiliá-los.

Com base nesses números, é possível perceber que se torna inviável garantir a celeridade da tramitação processual e a duração razoável (artigo $5^{\circ}$, inciso LXXVIII da CR/88), bem como a solução integral de mérito (artigo $4^{\circ}$ do Código de Processo Civil) (BRASIL, 2015).

Para que fosse possível verificar o tempo de tramitação dos feitos nos tribunais, o CNJ analisou o tempo médio gasto da distribuição até o proferimento da sentença; o tempo médio de baixa, ou seja, a data de início de cada fase processual até a sua baixa (por exemplo, o tempo gasto entre a distribuição do feito até o início da fase de execução); e, por fim, a duração medida de processos pendentes (dentre outros motivos, aqueles que voltaram a tramitar por decisões anuladas em recursos ou conflitos de competência) (BRASIL, 2020a).

Tabela 4 - Tempo médio de tramitação nos Tribunais Superiores

\begin{tabular}{lccc}
\hline \multicolumn{1}{c}{ Órgão } & Sentença & Baixa & Pendente \\
\hline Superior Tribunal de Justiça (STJ) & $9 \mathrm{~m}$ & 1a e $6 \mathrm{~m}$ & 2a e 6m \\
Tribunal Superior do Trabalho & 1a e $4 \mathrm{~m}$ & 1a e $6 \mathrm{~m}$ & 2a e 1m \\
\hline
\end{tabular}

Fonte: Elaborado pelo autor com dados extraídos do CNJ (BRASIL, 2020a, p. 179). 
Tabela 5 - Tempo médio de tramitação no $2^{\circ} \mathrm{Grau}$

\begin{tabular}{lccc}
\hline \multicolumn{1}{c}{ Órgão } & Sentença & Baixa & Pendente \\
\hline Total & $10 \mathrm{~m}$ & $10 \mathrm{~m}$ & 2a e $1 \mathrm{~m}$ \\
Tribunais de Justiça Estaduais & $8 \mathrm{~m}$ & $1 \mathrm{a}$ & $2 \mathrm{a}$ e $6 \mathrm{~m}$ \\
Tribunais Regionais Federais & $2 \mathrm{a}$ & $2 \mathrm{a}$ e $5 \mathrm{~m}$ & $2 \mathrm{a}$ e $4 \mathrm{~m}$ \\
Tribunais Regionais do Trabalho & $5 \mathrm{~m}$ & $10 \mathrm{~m}$ & $1 \mathrm{a}$ \\
Turmas Recursal Estadual & $7 \mathrm{~m}$ & $8 \mathrm{~m}$ & $1 \mathrm{a} \mathrm{e} 10 \mathrm{~m}$ \\
\hline
\end{tabular}

Fonte: Elaborado pelo autor com dados extraídos do CNJ (BRASIL, 2020a, p. 179).

Tabela 6 - Tempo médio de tramitação no $1^{\circ} \mathrm{Grau}$

\begin{tabular}{|c|c|c|c|}
\hline Órgão & Sentença & Baixa & Pendente \\
\hline Conhecimento Total & $2 a$ & $1 \mathrm{a}$ & $3 a$ e $11 \mathrm{~m}$ \\
\hline Varas Estaduais & $2 a$ e $5 \mathrm{~m}$ & $3 a$ e $7 m$ & $4 a$ e $2 m$ \\
\hline Varas Federais & 1 a e $7 m$ & $2 a$ e $10 m$ & $3 a$ e $9 \mathrm{~m}$ \\
\hline Varas do Trabalho & $8 m$ & $1 a$ & 1 a e $1 \mathrm{~m}$ \\
\hline Juizados Especiais Estaduais & $9 m$ & 1 a e $6 m$ & 1 a e $10 \mathrm{~m}$ \\
\hline Juizados Especiais Federais & $1 a$ & 1 a e $9 m$ & 1 a e $5 \mathrm{~m}$ \\
\hline Execução Total & $4 a$ e $9 m$ & $6 a$ e $6 m$ & $7 a$ \\
\hline Varas Estaduais & $4 a$ e $9 m$ & $6 a$ e $11 \mathrm{~m}$ & $7 a$ \\
\hline Varas Federais & $7 a$ e $10 m$ & $8 a$ e $3 m$ & $8 a$ e $4 m$ \\
\hline Varas do Trabalho & $3 a$ e $11 \mathrm{~m}$ & $2 a$ e $6 m$ & $4 a$ e $10 m$ \\
\hline Juizados Especiais Estaduais & $1 \mathrm{a}$ e $2 \mathrm{~m}$ & $1 \mathrm{a}$ e $7 \mathrm{~m}$ & $2 a \mathrm{e} 3 \mathrm{~m}$ \\
\hline Juizados Especiais Federais & $7 \mathrm{~m}$ & 1a e $10 \mathrm{~m}$ & $11 \mathrm{~m}$ \\
\hline
\end{tabular}

Fonte: Elaborado pelo autor com dados extraídos do CNJ (BRASIL, 2020a, p. 179-180).

Somando-se todos os prazos necessários em cada instância e tribunal, o tempo médio de duração de um processo foi de 2 anos e 2 meses para serem sentenciados, 3 anos e 3 meses para serem baixados e 5 anos e 2 meses quando estavam pendentes (BRASIL, 2020a, p. 181).

Percebe-se claramente o prejuízo que o elevado número de feitos em tramitação acarreta para a população, pois em média, cada jurisdicionado deverá aguardar mais de 2 anos para que seu litígio seja decidido e caso seja necessário iniciar a execução, o tempo necessário aumentará para mais de 3 anos. Ademais, muito embora o objetivo da criação dos juizados especiais seja garantir maior celeridade aos feitos, a realidade se mostra outra, pois a 
parte terá que aguardar 9 meses para obter uma sentença nos Juizados Especiais Estaduais e 1 ano nos Juizados Especiais Federais.

Devido ao longo prazo na resolução do litígio, se a parte desistir do feito pela perda do objeto, por ter alcançado um acordo extrajudicial ou outro motivo qualquer, não só as partes, mas o Estado terão gastos desnecessários com custas iniciais, honorários advocatícios, infraestrutura, pessoal, equipamentos, espaço físico, dentre outros.

Manter órgãos autossuficientes, capazes de gastar menos para o seu funcionamento do que as receitas recebidas é essencial para que a população possa ter o devido o acesso as garantias básicas de subsistência. Entretanto, o Judiciário não se amolda a essa hipótese, pois no ano de 2019 , foi registrado um déficit total de $\mathrm{R} \$ 23,8$ bilhões, os quais precisaram ser complementados pelos cofres públicos. Igualmente, no biênio 2017-2018, o percentual de gastos necessários para a manutenção do Judiciário $(2,6 \%)$ foi praticamente inversamente proporcional ao de redução de seu acervo (3\%), porém, em 2019 o total gasto ultrapassou 100 bilhões de reais, ocasionando em um aumento de 7 bilhões de reais se comparado com 2018 (BRASIL, 2020a).

Portanto, considerar a alternativa de aumentar o efetivo de profissionais nos tribunais como forma de redução do acervo judicial é inviável, pois consequentemente majoraria o déficit Judiciário. Porém, a autocomposição se mostra uma alternativa viável para garantir o acesso à justiça, reduzir o acervo processual e tornar o órgão autossuficiente. Nesse sentido, o Código de Processo Civil (CPC), determina que operadores do Direito devem incentivar a utilização de métodos autocompostivos (artigo $3^{\circ}$ parágrafo $3^{\circ}$ ) e torna obrigatória após a distribuição da petição inicial, a realização de audiência de conciliação ou mediação (artigo 334) (BRASIL, 2015).

Após o CPC ter entrado em vigor em 2016, notou-se um aumento do índice de conciliações de 11,1\% em 2015 para 13,6\% em 2016, mas o ano 2019 foi marcado pelo terceiro ano consecutivo de redução no percentual de conciliações no Judiciário, sendo 13,5\% em 2017, 12,7\% em 2018 e 12,5\% em 2019 (BRASIL, 2020a).

Tabela 7 - Índice de Conciliação

\begin{tabular}{c|c|c|c}
\hline Ano & Índice & Total de Sentenças & $\begin{array}{c}\text { Sentenças homolo- } \\
\text { gatórias }\end{array}$ \\
\hline 2015 & $11,1 \%$ & 27,5 milhões & 3,05 milhões \\
2016 & $13,6 \%$ & 27,7 milhões & 3,77 milhões \\
2017 & $13,5 \%$ & 28,3 milhões & 3,82 milhões \\
2018 & $12,7 \%$ & 29,5 milhões & 3,75 milhões \\
2019 & $12,5 \%$ & 31,7 milhões & 3,96 milhões \\
\hline
\end{tabular}

Fonte: Elaborado pelo autor com dados extraídos do CNJ (BRASIL, 2020a).

Mesmo que se apresente como promissor, o percentual de resoluções autocompositivas no Judiciário se comparado com formas extrajudiciais de resolução de conflitos não se mos- 
tra tão efetivo. No ano de 20187 , enquanto o Judiciário obteve apenas 12,7\% (BRASIL, 2020a) de acordos firmados em conciliações, o percentual médio de resolução nos Procons foi de $76 \%$ e de $81 \%$ na plataforma Consumidor.gov.br foi de $81 \%$ (BRASIL, 2019d).

\title{
5. MÉTODOS ADEQUADOS DE SOLUÇÃO DE CONFLITOS
}

Os institutos extrajudiciais de solução de conflitos progressivamente têm sua importância reconhecida e passam a ser amplamente utilizados, portanto, a antiga denominação métodos alternativos é substituída por métodos adequados. Quando se denomina como "alternativos" os institutos se tornam uma opção substitutiva ao sistema consagrado (Judiciário) como principal predileção das partes. Contudo, quando se substitui para "adequados" essa presunção de hierarquia entre os métodos é retirada, de modo que se tornam semeIhantes e não mais "uma segunda opção".

\begin{abstract}
Reside aqui uma celeuma terminológica entre valer-se das expressões métodos "alternativos" ou "adequados". Quando se vale do primeiro, pressupõe-se que há uma via ordinária e, portanto, principal. Com a locução "métodos adequados" não há predisposições em favor de uma ou outra forma de resolução dos litígios, direcionando-se a avaliação tópica de pertinência. No caso, é inegável que atualmente no Brasil há ampla adesão à via heterocompositiva judicial, o que justifica plenamente a alusão às demais formas de resolução de disputas como métodos alternativos. Por outro lado, a apresentação da temática como tal condiciona a um comportamento de escolha subsidiária, o que se mostra inapto ao fomento e ao potencial que apresentam, o que parece justificar com ainda maior intensidade a escolha pela segunda expressão apresentada. (SCARPARO, 2018, p. 67).
\end{abstract}

Em qualquer sociedade humana o conflito é inerente e inevitável (SAMPAIO, 2016) e se considerarmos que os números hiperbólicos do acervo judicial nacional ocasionam a impossibilidade de se ter proferida uma resolução integral da lide em tempo hábil, é preciso analisar a utilização dos métodos adequados de solução de conflitos como capazes de garantir a efetividade do acesso à justiça.

Atualmente, o mais simples método adequado é a negociação que ocorre diretamente entre os envolvidos, trabalhando o conflito entre si sem qualquer intervenção de terceiros. Mesmo que o ato de negociar possa ser efetuado diretamente pelas partes, caso seja de seu interesse, poderão escolher que ela seja conduzidas por terceiros como na conciliação e mediação.

A utilização da conciliação é indicada em situações nas quais o conflito é objetivo, ou seja, as partes não possuem qualquer tipo de relacionamento significativo ou interesse em criar um. Normalmente, ocorrem em contratos de consumo, no qual o cidadão compra um bem e diante de um problema, quer somente a solução de sua situação.

Art. 165. Os tribunais criarão centros judiciários de solução consensual de conflitos, responsáveis pela realização de sessões e audiências de concilia-

7 Foram utilizados os dados de 2018, pois este foi o ano do último relatório disponibilizado pelo SENACON e por tal motivo, foram comparados com o relatório disponibilizado pelo CNJ referente ao mesmo ano. 
ção e mediação e pelo desenvolvimento de programas destinados a auxiliar, orientar e estimular a autocomposição.

[...]

$\S 2^{\circ} \mathrm{O}$ conciliador, que atuará preferencialmente nos casos em que não houver vínculo anterior entre as partes, poderá sugerir soluções para o litígio, sendo vedada a utilização de qualquer tipo de constrangimento ou intimidação para que as partes conciliem.

$\S 3^{\circ} 0$ mediador, que atuará preferencialmente nos casos em que houver vínculo anterior entre as partes, auxiliará aos interessados a compreender as questões e os interesses em conflito, de modo que eles possam, pelo restabelecimento da comunicação, identificar, por si próprios, soluções consensuais que gerem benefícios mútuos. (BRASIL, 2015).

Por outro lado, a mediação é o instituto que intenta a mais saudável solução para os imbróglios que vierem a existir, no qual o mediador atuara de forma indireta sendo o agente facilitador da comunicação entre os envolvidos em busca de uma solução de ganhos mútuos.

O CNJ define a mediação é como uma negociação integrativa (que as partes buscam uma solução em que ambas ganhem) intermediada por um ou mais mediadores imparciais e neutros, que irão facilitar a comunicação entre as partes de modo que possam compreendam seus interesses e criem soluções que tragam mudanças positivas e ganhos mútuos (BRASIL, 2016). Conforme explica Fredie Didier Júnir, a diferença entre a conciliação e a mediação é tênue:

A diferença entre a conciliação e a mediação é sutil - e talvez, em um pensamento analiticamente mais rigoroso, inexistente, ao menos em seu aspecto substancial. A doutrina costuma considerá-las como técnicas distintas para a obtenção da autocomposição.

0 conciliador tem uma participação mais ativa no processo de negociação, podendo, inclusive, sugerir soluções para o litígio. A técnica da conciliação é mais indicada para os casos em que não havia vínculo anterior entre os envolvidos.

O mediador exerce um papel um tanto diverso. Cabe a ele servir como veículo de comunicação entre os interessados, um facilitador do diálogo entre eles, auxiliando-os a compreender as questões e os interesses em conflito, de modo que eles possam identificar, por si mesmos, soluções consensuais que gerem benefícios mútuos. Na técnica da mediação, o mediador não propõe soluções aos interessados. Ela é por isso mais indicada nos casos em que exista uma relação anterior e permanente entre os interessados, como nos casos de conflitos societários e familiares. A mediação será exitosa quando os envolvidos conseguirem construir a solução negociada do conflito. (DIDIER JÚNIOR, 2016, p. 274).

Por ter como objetivo principal o consenso em qualquer um dos métodos utilizados, os envolvidos não são obrigados a atingir uma transação ao final do procedimento utilizado, sendo garantido que a qualquer momento os trabalhos sejam interrompidos, sem que isso cerceie a busca pelo Judiciário.

Carlos Vasconcelos ensina que em uma disputa adversarial como a judicial ou arbitral, a comunicação já está consideravelmente perdida e a cada fala ou argumento, estes serão recebidos como um ataque e ao invés de expor quais são os reais interesses, a parte con- 
trária apresentará um novo argumento para rebater o que foi apresentado (VASCONCELOS, 2018).

O que geralmente ocorre no conflito processado com enfoque adversarial é a hipertrofia do argumento unilateral, quase não importando o que o outro fala ou escreve. Por isso mesmo, enquanto um se expressa, o outro já prepara uma nova argumentação. Ao identificarem que não estão sendo entendidas, escutadas, lidas, as partes se exaltam e dramatizam, polarizando ainda mais as posições.

A solução transformadora do conflito depende do reconhecimento das diferenças e da identificação dos interesses comuns e contraditórios, subjacentes, pois a relação interpessoal funda-se em alguma expectativa, valor ou interesse comum.

[...]

O conflito, quando bem conduzido, pode resultar em mudanças positivas e novas oportunidades de ganho mútuo. (VASCONCELOS, 2018).

Para Roger Fisher, Willian Ury e Bruce Patton, para que os envolvidos possam atingir seu objetivo, devem ser utilizadas técnicas capazes de maximizar o resultado. 0 procedimento proposto pelos autores possui quatro etapas, quais sejam: separar pessoas dos problemas, concentrar em interesses e não em posições, criar opções de ganhos mútuos e focar em critérios objetivos (FISHER, URY e PATTON, 2018).

Separar pessoas dos problemas significa retirar a parte emocional dos conflitos, de modo que o envolvido possa compreender a discussão de uma posição neutra sem o seu caráter sentimental. Normalmente, quando um ato é realizado por alguém com quem o indivíduo já possui alguma rusga e por outra pessoa com quem possui grande apreciação, no primeiro caso será agravado pelos sentimentos negativos, enquanto no segundo poderá ser recebido sem maiores repercussões. Portanto, ao tirar o elemento sentimental do conflito, é possível observá-lo de uma posição neutra para aumentar a confiança entre as partes e reduzir os ruídos na comunicação.

Concentrar em interesses e não em posições é compreender o que o indivíduo realmente quer e não o que aparenta querer. Não raras vezes, duas pessoas querem o mesmo objeto (posições), mas por motivos diferentes (interesses). Por exemplo, dois irmãos estão discutindo para decidir quem terá o direito de dirigir o veículo da família (essa é a posição deles, querem o veículo), então, a solução lógica é que façam um revezamento do bem, o que não fará com que ambos fiquem satisfeitos. Contudo, após aprofundar um pouco mais no conflito, descobrem que um dos irmãos quer o carro para ir para sua faculdade no período noturno e o outro no período diurno (esse é o interesse).

Após explorar o conflito, é possível buscar opções de ganhos mútuos. No caso apresentado como os interesses não são conflituosos, bastaria dividirem a utilização do veículo por período do dia e ambos terão seus interesses completamente satisfeitos, ao contrário da solução baseada nas posições, que além de não resolver o imbróglio, faria com que o bem ficasse ocioso no momento que o outro poderia usar.

Por fim, para focar em critérios objetivos as partes não devem discutir por parâmetros que não são possíveis de serem realizados, pois por mais que cheguem a um acordo, se for inviável, manter a discussão naquele ponto somente traria desgastes e conturbaria ainda 
mais a relação. Também pode ser entendido como a utilização de padrões já pré-estabelecidos como tabela de preço, normas jurídicas ou avaliações de peritos.

Qualquer método de negociação pode ser julgado imparcialmente conforme três critérios: deve levar a um acordo sensato caso ele seja possível, deve ser eficiente e deve melhorar ou, pelo menos, não prejudicar a relação entre as partes. (Um acordo sensato pode ser definido como aquele que, na medida do possível, atende aos interesses legítimos de cada lado, resolva conflitos de interesses de forma justa, é durável e leva em conta os interesses da comunidade.

(FISHER; URY; PATTON, 2018).

Utilizando o auxílio de técnicas de negociação, abandona-se o caráter amador e instintivo de uma negociação para um procedimento técnico e bem trabalhado em busca de um acordo em que todos os interesses são sanados e nenhuma das partes sinta-se em desvantagem em relação a outra.

Portanto, ao utilizar os métodos adequados de solução de conflito, não só as partes diretamente interessadas se beneficiaram, pois terão seu dilema resolvido em tempo hábil, de maneira adequada e certa, como a estrutura do Judiciário, que com a consequente redução de novos processos poderá ter tempo hábil e adequado para solucionar o acervo já existente e os novos casos que surgirem.

\section{CONCLUSÁO}

Diante dos dados apresentados, é possível perceber que o número de feitos em tramitação existentes em nossos tribunais impossibilita que as partes possam obter o resultado integral do feito em tempo hábil, de modo que o princípio do acesso à justiça não é integralmente garantido. No ano de 2019, mesmo que tenha encerrado com uma redução no acervo, o percentual ainda é baixo e se for mantida a tendência, o tempo necessário para que os feitos em tramitação sejam encerrados será de vários anos.

Outrossim, o Judiciário não tem conseguido ser autossuficiente financeiramente, encerrando cada ano com um déficit bilionário, o que inviabiliza a hipótese de aumentar a mão de obra (servidores e magistrados) já existente. Igualmente, exigir que os processos sejam julgados em tempo reduzido, acarretaria decisões que sem ter sido dispendido o tempo necessário para a convicção do magistrado, trariam insatisfação para as partes e insegurança jurídica para a população.

Garantir que a população possa levar seus litígios para apreciação judicial somente é parte do princípio do acesso à justiça, que parar ser integralmente efetivado os mesmos devem ser julgados de maneira adequada e em tempo hábil.

Para mudar esse cenário, é necessária uma mudança de cultura na sociedade que deve abdicar da litigiosidade para em um primeiro momento utilizar a autocomposição resolução de seus conflitos e somente diante da impossibilidade de um acordo, judicializar sua demanda. Nesse sentido, os métodos adequados de solução de conflitos, possuem procedimentos mais céleres e menos oneroso para as partes, bem como com o auxílio de técnicas 
de negociação permitem que as partes compreendam o conflito e em conjunto almejem uma solução de ganhos mútuos.

Ao se utilizar métodos adequados de solução de conflitos (autocompositivos), é possível reduzir os custos e proporcionar maior celeridade na resolução dos conflitos, de modo que os envolvidos possam assumir a função de atores principais em sua demanda. Igualmente, quando profissionais adequadamente especializados utilizam técnicas de negociação, é possível que em conjunto busquem uma solução que acarrete benefícios mútuos.

Independentemente da forma que a autocomposição for trabalhada (uma negociação diretamente feita pelos envolvidos ou com o auxílio de um terceiro), é possível almejar um termo que seja satisfatório. Ao abandonar o caráter acusatório impositivo de um processo judicial ou heterocomposição, as partes poderão identificar as necessidades, dores e opções do outro, dispendendo o tempo necessário para negociar, sem que exista a incerteza do judiciário em que somente ao final da lide será possível saber o resultado.

Logo, como o Brasil não possui recursos financeiros suficientes para aumentar a estrutura do Judiciário, bem como exigir maior celeridade dos magistrados acarretaria prejuízos para a população, o princípio do acesso à justiça atrelado somente à jurisdição não é efetivamente garantido. Conclui-se como de essencial importância a sobreposição da cultura do litígio pela cultura da autocomposição. De modo que com a utilização de métodos adequados de solução de conflitos, será garantido aos cidadãos o efetivo acesso à justiça, além do controle da decisão de seus conflitos visando acordos que tragam benefícios para todos os envolvidos

Ademais, além dos benefícios trazidos para as partes diretamente envolvidas, permitem uma diminuição do acervo judicial, vez que com a redução da distribuição de novos feitos, os magistrados e servidores poderão se encarregar dos casos já existentes e dispender o tempo necessário para sua solução.

\section{REFERÊNCIAS}

ALBuquerque, Aline; BARRoso, Aléssia. Curso de Direitos Humanos. Rio de Janeiro: Lumen Juris, 2018.

ANNONI, Danielle. O Direito humano de acesso à justiça em um prazo razoável. 2006. 346 f. Tese (Doutorado) Curso de Pós-graduação em Direito, Universidade Federal de Santa Catarina, Florianópolis. 2006. Disponível em: https://repositorio.ufsc.br/handle/123456789/89512. Acesso em: 22 nov. 2020.

ARISTÓTELES. Ética a Nicômaco. Tradução de Leonel Vallandro e Gerd Hornheim. Pinheiros: Nova Cultural, 1991. BOBBIO, Norberto. O Futuro da Democracia - Uma Defesa das Regras do Jogo. Tradução de Marco Aurélio Nogueira. 2. ed. Rio de Janeiro, Paz e Terra, 1986.

BONAVIDES, Paulo. Do Estado Liberal ao Estado Social. 7. ed. São Paulo: Malheiros Editores, 2001.

BRASIL. Ato Institucional n² 2, de 27 de outubro de 1965. Diário Oficial da União, Brasília, 27 out. 1965. Disponível em: http://www.planalto.gov.br/ccivil_03/AIT/ait-02-65.htm. Acesso em: 22 nov. 2020.

BRASIL. Ato Institucional n 5, de 13 de dezembro de 1968. Diário Oficial da União, Brasília, 13 dez. 1968. Disponível em: http://www.planalto.gov.br/ccivil_03/ait/ait-05-68.htm. Acesso em 22 nov. 2020.

BRASIL. Código de Processo Civil. Diário Oficial da União, Brasília, 16 mar. 2015a. Disponível em: http://www. planalto.gov.br/ccivil_03/_ato2015-2018/2015/lei/l13105.htm. Acesso em: 22 nov. 2020. 
BRASIL. Conselho Nacional de Justiça. Justiça em Números 2020: ano-base 2019. Brasília: CNJ, 2020a. Disponível em: https://www.cnj.jus.br/wp-content/uploads/2020/08/WEB-V3-Justi\%C3\%A7a-em-N\%C3\%BAmeros-2020-atualizado-em-25-08-2020.pdf. Acesso em: 22 nov. 2020.

BRASIL. Conselho Nacional de Justiça. Manual de Mediação Judicial: De acordo com a Lei 13.140/15 (Lei de Mediação), a Lei 13.105/15 (Novo Código de processo Civil) e a Emenda 2 da Resolução 125/10. 6. ed. Brasília: CNJ, 2016. Disponível em: https://www.cnj.jus.br/wp-content/uploads/2015/06/f247f5ce60df2774c59d6e2dddbfec54.pdf. Acesso em: 22 nov. 2020.

BRASIL. Conselho Nacional de Justiça. Quem somos. 2020b. Disponível em: https://www.cnj.jus.br/sobre-o-cnj/ quem-somos/. Acesso em: 22 nov. 2020.

BRASIL. Constituição da República Federativa do Brasil. Diário Oficial da União, Brasília, 05 out. 1988. Disponível em: http://www.planalto.gov.br/ccivil_03/constituicao/constituicao.htm. Acesso em: 22 nov. 2020.

BRASIL. Constituição dos Estados Unidos do Brasil. Diário Oficial da União, Rio de Janeiro, 19 set. 1946. Disponível em: http://www.planalto.gov.br/ccivil_03/constituicao/constituicao46.htm. Acesso em: 22 nov. 2020.

BRASIL. Emenda Constitucional n 11, de 13 de outubro de 1978. Altera dispositivos da Constituição Federal. Diário Oficial da União, Brasília, 13 out. 1978. Disponível em: http://www.planalto.gov.br/ccivil_03/Constituicao/ Emendas/Emc_anterior1988/emc11-78.htm. Acesso em: 22 nov. 2020

BRASIL. Secretaria Nacional Do Consumidor. Consumidor em números: Reclamações de consumo em 2018. 2019. Disponível em: https://www.justica.gov.br/news/collective-nitf-content-1552676889.94/arquivos/consumidor-em-numeros-2018_portal.pdf. Acesso em: 22 nov. 2020.

BRASIL. Superior Tribunal De Justiça. Recurso Especial 1.149. 487/RJ, Ministro Relator Antônio Carlos Ferreira, julgado em 06 dez. 2018, publicado no Diário da Justiça eletrônico em 15 fev. 2019. Disponível em: https://scon. stj.jus.br/SCON/GetInteiroTeorDoAcordao?num_registro=200901327733\&dt_publicacao=15/02/2019. Acesso em: 22 nov. 2020.

BRASIL. Superior Tribunal De Justiça. Agravo Interno no Recurso Especial 1.141.490/RJ, Ministro Relator Antônio Carlos Ferreira, julgado em 06 dez. 2018, publicado no Diário da Justiça eletrônico em 14 fev. $2019 \mathrm{~g}$. Disponível em: https://scon.stj.jus.br/SCON/GetInteiroTeorDoAcordao?num_registro=200901310978\&dt_publicacao=14/02/2019. Acesso em: 22 nov. 2020.

BRASIL. Supremo Tribunal Federal. Agravo de Instrumento 761.820/RJ, Ministra Relatora Rosa Weber, julgado em 18 ago. 2020, publicado no Diário da Justiça eletrônico em 25 ago. 2020d. Disponível em: http://portal.stf.jus.br/ processos/downloadPeca.asp?id=15344146749\&ext=.pdf. Acesso em: 22 nov. 2020.

BRASIL. Supremo Tribunal Federal. Agravo de Instrumento 764.506/RJ, Ministra Relatora Rosa Weber, julgado em 18 ago. 2020, publicado no Diário da Justiça eletrônico em 25 ago. 2020e. Disponível em: http://portal.stf.jus.br/ processos/downloadPeca.asp?id=15344147487\&ext=.pdf. Acesso em: 22 nov. 2020.

BRASIL. Supremo Tribunal Federal. Agravo Regimental no Recurso Extraordinário com Agravo 1.250.467/RJ, Ministra Relatora Rosa Weber, julgado em 29 jun. 2020, publicado no Diário da Justiça eletrônico em 05 ago. 2020f. Disponível em: http://redir.stf.jus.br/paginadorpub/paginador.jsp?docTP=TP\&doclD=753386305. Acesso em: 22 nov. 2020.

CAMARGOS, Laís Alves. O direito constitucional ao recurso e à fundamentação das decisões: estudo crítico do julgamento em única instância pelos tribunais de $2^{\circ}$ grau. Dissertação. (Mestrado) - Universidade FUMEC, Belo Horizonte, 2020.

CUNHA, José Sebastião Fagundes. Da conciliação, da mediação e da arbitragem endoprocessual e o novo Código de processo civil. In: Revista eletrônica [do] Tribunal Regional do Trabalho da 9a Região: v. 4, n. 44, p. 50-70, set. 2015. Disponível em: https://juslaboris.tst.jus.br/bitstream/handle/20.500.12178/89494/2015_cunha_jose_conciliacao_mediacao.pdf?sequence=1\&isAllowed=y. Acesso em: 22 nov. 2020

DIDIER JÚNIOR, Fredie. Curso de direito processual civil: introdução processual civil, parte geral e processo de conhecimento. 18. ed. Salvador: Juspodivm, 2016.

ECHR. European Court of Human Rights. Convenção Europeia dos Direitos Humanos, adotada em 4 de novembro de 1950. 1950. Disponível em: https://www.echr.coe.int/Documents/Convention_POR.pdf. Acesso em 22 nov. 2020. 
FISHER, Roger; URY, William; PATTON, Bruce. Como chegar ao sim: Como negociar acordos sem fazer concessões. Tradução de Rachel Agavino. Rio de Janeiro: Sextante, 2018. E-book.

GORDILLO, Agustín. Princípios Gerais de Direito Público. Trad. Brasileira de Marco Aurélio Greco. São Paulo: RT, 1977.

LIBRARY, British. English translation of Magna Carta. 2014. Disponível em: https://www.bl.uk/magna-carta/articles/magna-carta-english-translation. Acesso em: 25 set. 2020.

MAGALHÃES, José Luiz Quadros de. Direito Constitucional. Tomo I. 2. ed. Belo Horizonte: Mandamentos, 2002.

MARX, Karl Heinrich. O Capital. Traduzido por Ronaldo Alves Schmidt. 8 ed. Rio de Janeiro: LTC, 2018. E-book.

MARX, Karl Heinrich; ENGELS, Friedrich. O manifesto comunista. Traduzido por Débora Landsberg. São Paulo: Expresso Zahar, 2014.

MORAIS, Márcio Eduardo Pedrosa. "Pensar a justiça no século vinte e um: um breve estudo sobre os pensamentos de Aristóteles e de Rawls sobre a justiça e sua aplicabilidade no Estado Democrático de Direito." In: XVI Congresso Nacional do CONPEDI. Florianópolis: CONPEDI, 2007. Disponível em: http://www.publicadireito.com. br/conpedi/manaus/arquivos/anais/bh/marcio_eduardo_da_silva_pedrosa_morais.pdf. Acesso em 22 nov. 2020.

RAWLS, John. Uma teoria da justiça. Tradução de Almiro Pisetta e Lenita M. R. Esteves. São Paulo: Martins Fontes, 2000

ROCHA, José Cláudio; ALVES, Cristiano Cruz. 0 acesso à justiça: ao Poder Judiciário ou à ordem jurídica justa? Revista Meritum. Belo Horizonte, v. 6, n. 1, p. 133-161, jan./jul. 2011. Disponível em: http://www.fumec.br/revistas/meritum/article/view/1068/761. Acesso em: 22 nov. 2020.

SALLES, Bruno Makowiecky. Acesso à justiça e equilíbrio democrático: intercâmbios entre Civil Law e Common Law. 2019. 509 f. Tese (Doutorado) - Curso de Doutorado em Ciência Jurídica da Universidade do Vale do Itajaí - UNIVALI, Itajaí. 2019. Disponível em: https://www.univali.br/Lists/TrabalhosDoutorado/Attachments/264/ TESE\%20BRUNO\%20MAKOWIECKY\%20SALLES\%20-\%20TOTAL.pdf. Acesso em: 22 nov. 2020.

SAMPAIO, Lia Regina Castaldi. Teoria geral do conflito - visão da Psicologia In: BACELLAR, Roberto Portugal (Coord.). Conciliação e Mediação - ensino em construção. São Paulo: IPAM - Instituto paulista de magistrados, 2016. p. $320-325$.

SARMENTO, Daniel. Direitos Fundamentais e Relações Privadas. 2. ed. Rio de Janeiro: Lumen Juris, 2006.

SCARPARO, Eduardo. Negociando estrategicamente em litígios cíveis. In: MACEDO, Elaine Harzheim; DAMASCENO, Marina (org.). Sistema multiportas e métodos integrados de resolução de conflitos. Porto Alegre: ediPUCRS, 2018. p. 63-104.

SEIXAS, Bernardo Silva de; SOUZA, Roberta Kelly Silva. Evolução histórica do acesso à justiça nas constituições brasileiras. Revista de Direito e Democracia, v. 14, n.1, p. 68-85, jan./jun. 2013. Disponível em: http://www.periodicos.ulbra.br/index.php/direito/article/view/2660/1883. Acesso em: 22 nov. 2020.

SILVA, Adriana dos Santos. Acesso à justiça e arbitragem: um caminho para a crise do judiciário. Barueri: Manole, 2005

SMITH, Adam. A Riqueza das Nações: Investigações sobre a Natureza e suas causas. São Paulo: Nova Cultural Ltda., 1996.

VASCONCELOS, Carlos Eduardo de. Mediação de conflitos e práticas restaurativas. 6. ed. São Paulo: Método, 2018. E-book.

ZANFERDINI, Flávia de Almeida Montingelli; MAZZO, Fernando Henrique Machado. Do movimento de acesso à justiça às preocupações sobre o aumento da litigiosidade de massa. Revista Meritum. Belo Horizonte, v. 10, n. 1, p. 77-100, jan./jun. 2015. Disponível em: http://www.fumec.br/revistas/meritum/article/view/3369/1814. Acesso em 22 nov. 2020

Recebido/Received: 30.09.2020.

Aprovado/Approved: 25.11.2020. 